\title{
Understanding and Defining the Socially Conscious Consumer
}

\author{
Alexis Croswell, Kevin Lehnert, and Christian Hinsch
}

\begin{abstract}
With the growing research on the impact of corporate social responsibility (CSR) programs, there is relatively little research on the makeup of the socially conscious consumer. This is particularly true with regard to their response to socially responsible initiatives. We address this gap through a qualitative study which ascertains the general mindset and makeup of the socially conscious consumer. Results indicate that socially conscious consumers use rational economic models in their consumption decisions, weighing the costs and benefits of their choices. This group also displays a general skepticism with respect to CSR tactics. This has distinct implications for managers, as it becomes more important for them to change the consumer's view towards marketing than to enhance the existing social viewpoints of the consumer.
\end{abstract}

\section{References available upon request.}

A. Croswell $\bullet$ K. Lehnert $(\square) \bullet$ C. Hinsch

Grand Valley State University, Allendale, MI 49401, USA

e-mail: croswela@mail.gvsu.edu; lehnertk@gvsu.edu; hinschc@gvsu.edu 